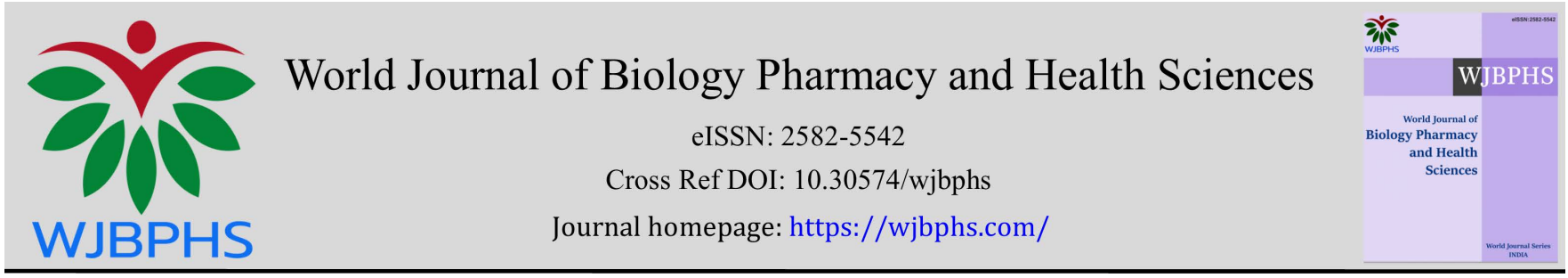

(RESEARCH ARTiCLE)

\title{
Determination of $\beta$-carotene in jute leaves by spectrophotometry and thin layer chromatography
}

\author{
Mst. Aleya Nasreen ${ }^{1,}{ }^{*}$, Zakaria Ahmed ${ }^{2}$, Md. Mahabub Ali ${ }^{3}$ and Tahmina ${ }^{1}$ \\ ${ }^{1}$ Microbiology and Biochemistry Department, Technology Wing, Bangladesh Jute Research Institute, Manik Mia Avenue, \\ Dhaka-1207, Bangladesh. \\ 2 Mechanical Processing Division, Technology Wing, Bangladesh Jute Research Institute, Manik Mia Avenue Dhaka-1207, \\ Bangladesh. \\ ${ }^{3}$ Jute Seed Production and Research Center, Dinajpur, Bangladesh Jute Research Institute, Bangladesh.
}

World Journal of Biology Pharmacy and Health Sciences, 2022, 09(02), 011-020

Publication history: Received on 07 January 2022; revised on 08 February 2022; accepted on 10 February 2022

Article DOI: https://doi.org/10.30574/wjbphs.2022.9.2.0038

\begin{abstract}
$\beta$-carotene is a carotenoid pigment that converts to vitamin A in human body and plays crucial role in visual functions, reproductive performance and immune system. Jute leaves contain $\beta$-carotene but amounts in different varieties of jute leaves are not known. The study was undertaken to estimate the $\beta$-carotene content in fresh jute leaves of the cultivated jute species Corchorus olitorius L. and Corchorus capsularis L. by spectrophotometry and thin layer chromatography. $\beta$ carotene content varies in leaves of different varieties of two species. Leaves of some $C$. olitorius variety showed higher amount of $\beta$-carotene than the leaves of $C$. capsularis variety. Some varieties of $C$. olitorius showed similarity with some varieties of $C$. capsularis. Variety Robi- 1 of $C$.olitorius showed the highest content of $\beta$-carotene $39.93 \mathrm{mg} / 100 \mathrm{~g}$. 0-72, 04, 0-3820, 0-9897 and OM-1 of olitorius variety showed higher $\beta$-carotene than all the varieties of $C$. capsularis. JRO524 and MG-1 of $C$. olitorius variety is comparable to CVL-1, D-154, BJC-2197 and deshi pat shak-1 variety of $C$. capsularis regarding $\beta$-carotene content. Lowest $\beta$-carotene was estimated $12.55 \mathrm{mg} / 100 \mathrm{~g}$ in $0-795$ of olitorius variety and $12.32 \mathrm{mg} / 100 \mathrm{~g}$ in BJC-83 and $11.34 \mathrm{mg} / 100 \mathrm{~g}$ in BJC-2142 of capsularis variety. Thin layer chromatography system silica gel on TLC Al foils as stationary phase and hexane as mobile phase performs good separation and identification of $\beta$ carotene in jute leaves.
\end{abstract}

Keywords: $\beta$-carotene; Jute leaves; Corchorus olitorius; Corchorus capsularis; Spectrophotometry; Thin layer chromatography

\section{Introduction}

Jute (Corchorus sp.) leaves consumed as vegetable in many countries in Asia and Africa [1-3]. Edible species of Corchorus are very good source of proteins, vitamins (A, C, E), mineral nutrients like calcium, iron and carotenoid like lycopene [4$6]$. Previous research mentioned that jute leaves are rich source of beta carotene $[7,8]$. Beta carotenes present as micronutrients in fruits and vegetables and are responsible for their bright orange, red and yellow colours. In the plant carotenoids act as photosynthetic accessory pigments and also play a protective function as scavengers of oxygen radicals released from chloroplasts during photosynthesis, thus protecting cellular constituents such as DNA from free radical damage $[9,10]$. One of the most physiological functions of carotenoids in human nutrition is to act as pro-vitamin A (vitamin A precursors). Many studies show strong correlations between carotenoids intake and reduced risk of some diseases, such as cancers [11], artherogenesis [12,13], bone calcification [14], eye degeneration [15,16] immune function [17-19] and neuronal damage [20]. Based on the epidemiological studies a positive link is suggested between

${ }^{*}$ Corresponding author: Mst. Aleya Nasreen

Microbiology and Biochemistry Department, Technology Wing, Bangladesh Jute ResearchInstitute, Manik Mia Avenue, Dhaka-1207, Bangladesh.

Copyright (@) 2022 Author(s) retain the copyright of this article. This article is published under the terms of the Creative Commons Attribution Liscense 4.0. 
higher dietary intake and tissue concentration of carotenoids and lower risk of chronic diseases [21, 22]. Carotenoids may play a key role as free-radical scavenger and antioxidants in human body tissues [23, 24].

B-carotene belongs to the carotene class, which is one of the most abundant carotenoids found in the diet. Fruits and vegetables constitute major source of carotenoids in human diet [21,22]. Nutrition rich vegetables get attention in some region like Sub-Saharan Africa to combat malnutrition and famine. Among other vegetables, Corchorus spp. has been identified as promising for up-scaling and addressing food security [25]. Therefore, for the perspective of food security, usefulness and nutritional value of indigenous leafy vegetables like jute (Corchorus spp.) is required to be rediscovered. There is growing demand of jute leaves for up scaling as its well-known health benefit. Rediscovering nutritional value of jute leaves may be helpful to promote market potentiality as well as awareness among common people. Extraction and estimation procedure of carotenoids are rather complex. High performance liquid chromatography (HPLC) is commonly used for determination of $\beta$-carotene. HPLC requires expensive instrument and skillful operation. This work was aimed to investigate the $\beta$-carotene content of commercially cultivated jute leaves by simple spectrophotometry and thin layer chromatography (TLC).

\section{Material and methods}

\subsection{Plant sample}

Jute leaves of nine varieties of Corchorus olitorius and ten varieties of Corchorus capsularis were collected from the experimental field of Breeding Division of Bangladesh Jute Research Institute (BJRI), Dhaka, Bangladesh. The site belongs to the Agro Ecological Zone-8 namely, young Brahmaputra and Jamuna Floodplain. Cultural activities were performed according to Chowdhury and Hassan [26]. Fresh healthy jute leaves of selected varieties were harvested from 75 days old jute plant for estimation of $\beta$-carotene content. Three biological replications were used for each sample.

\subsection{Chemicals and Instruments}

- $\quad$ Tetrahydrofuran (THF), Dichloromethane (DCM), $\mathrm{NaCl}, \mathrm{Na}_{2} \mathrm{CO}_{3}$, Hexane and Trans $\beta$-carotene (Sigma-Aldrich, Germany).

- $\quad$ Silica gel on TLC Al foils and capillary pipette (Sigma-Aldrich, Germany)

- $\quad$ Centrifuge (Hitachi CR22N high-speed refrigerated centrifuge, Tokyo, Japan) and Spectrophotometer (UV6300 PC, VWR, Radnor, PA)

\subsection{Estimation of $\beta$-carotene using Spectrophotometry}

Spectrophotometric method for estimation of $\beta$-carotene was followed according to Karnjanawipagul et al. [27]. $\beta$ carotene from jute leaves samples was extracted by the procedures described by Herrero-Martinez et al. [28] with little modification. Briefly, jute leaves were washed with de-ionized water and chopped. Leaves (10g) were mixed with anhydrous $\mathrm{Na}_{2} \mathrm{CO}_{3}(1 \mathrm{~g})$ and homogenized with blender. Homogenized leaves $(10 \mathrm{~g})$ were transferred into a centrifuge tube and Tetrahydrofuran $20 \mathrm{ml}$ was added in it then kept it in the refrigerator overnight. The mixture was centrifuged at $5000 \mathrm{rpm}$ for $5 \mathrm{~min}$ by the centrifuge and supernatant was collected. Dichloromethane $15 \mathrm{ml}$ was added to the collected supernatant and then $\mathrm{NaCl}(10 \%)(\mathrm{w} / \mathrm{v}) 15 \mathrm{ml}$ was added to it and shaken for two min. The extraction was repeated twice, and organic layer was collected in evaporating bowl and placed in the refrigerator $\left(4^{\circ} \mathrm{C}\right)$ for $2 / 3 \mathrm{days}$ for evaporation in cold. The residue was collected and kept at $-20^{\circ} \mathrm{C}$. Afterwards reconstitute with $5 \mathrm{ml}$ DCM and diluted $(1 / 40$-fold) with DCM prior measurement by spectrophotometer (UV-6300 PC, VWR, Radnor, PA). $\beta$-carotene samples were measured at $461 \mathrm{~nm}$.

\subsection{Detection of $\beta$-carotene using thin layer chromatography}

$\beta$-carotene was detected by thin layer chromatography using the same sample extracted previously for spectrophotometric measurement. The sample was preserved at $-20^{\circ} \mathrm{C}$ and used for TLC work afterwards. An accurately weighted Trans $\beta$-carotene standard was dissolved in DCM to obtain a solution of $100 \mu \mathrm{g} / \mathrm{ml}$. Aliquot of standard solution was applied on TLC plate to compare with jute leaves extract of $\beta$-carotene. Silica gel on Al foil was stationary phase and hexane was mobile phase. Capillary pipette was used for placing samples on the TLC plate. Silica gel Al foil sheet were cut as per requirements such as $10 \mathrm{~cm} \times 8.5 \mathrm{~cm}$ for sample $01-05,10 \mathrm{~cm} \times 7.5 \mathrm{~cm}$ for sample $06-09,10 \mathrm{~cm} \times 9 \mathrm{~cm}$ for sample C1-C5 and $10 \mathrm{~cm} \times 9 \mathrm{~cm}$ for sample C6 -C10. A horizontal line was drawn by pencil about $1.2 \mathrm{~cm}$ above from the bottom of the TLC sheet. Capillary tube was dipped in the sample and gently touched it on the pencil drawn line of the TLC plate to empty it. Several pipettes were used for every individual sample. Several short touches were given to 
empty capillary, so the spot was $1-2 \mathrm{~mm}$ in diameter. Standard Trans $\beta$-carotene $(100 \mu \mathrm{g} / \mathrm{ml})$ was used on every plate as standard to compare with jute leaf extract $\beta$-carotene. Spots were allowed to dry. Afterwards the TLC sheet with spotted end was placed in a beaker in the developing solvent (hexane). The start spotted line was above the solvent level. Then beaker was covered with glass plate. Solvent was allowed to rise up the TLC plate leaving undisturbed until about $80 \%$ of TLC plate is wet. The TLC plate was then removed and taken photo immediately.

\subsection{Preparation of standard $\beta$-carotene solution}

Standard Trans $\beta$-carotene weighted exactly $0.4 \mathrm{mg}(400 \mu \mathrm{g})$ was dissolved in $100 \mathrm{ml}$ DCM to obtain $4 \mu \mathrm{g} / \mathrm{ml} \beta$-carotene solution. This solution was used for calibration curve preparation. The calibration curve was constructed by plotting the concentration versus the corresponding absorbance (Figure 1).

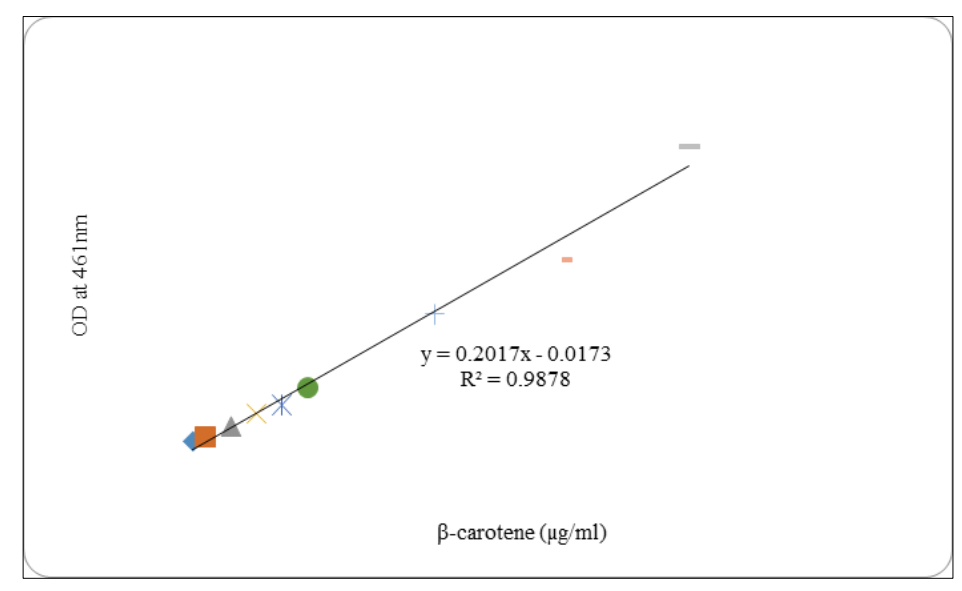

Figure 1Calibration curves of $\beta$-carotene at 0.1 to $4.0 \mu \mathrm{g} / \mathrm{ml}$

\section{Results}

\subsection{Estimation of $\beta$-carotene by spectrophotometry}

$\beta$-carotene content in jute leaves of different varieties of $C$. olitorius and $C$. capsularis were presented in Table 1 . Leaves of varieties of $C$. olitorius contain $\beta$-carotene $12.55 \mathrm{mg} / 100 \mathrm{~g}$ to $39.93 \mathrm{mg} / 100 \mathrm{~g}$. VarietyRobi-1 contain highest amount of $\beta$-carotene $39.33 \mathrm{mg} / 100 \mathrm{~g}$. Variety 0-72, 0-4 and 0-3820 contain the next highest 30.46, $29.05 \mathrm{and} 28.93 \mathrm{mg} / 100 \mathrm{~g}$ $\beta$-carotene respectively after Robi-1. Variety 0-9897, OM-1, JR0-524 and MG-1 have medium amount, 25.67, 24.41, 22.93 and $20.22 \mathrm{mg} / 100 \mathrm{~g} \beta$-carotene and $0-795$ contain lowest amount of $\beta$-carotene $12.55 \mathrm{mg} / 100 \mathrm{~g}$ in comparison to other $C$. olitorius varieties. $\beta$-carotene ranged 11.34 to $22.28 \mathrm{mg} / 100 \mathrm{~g}$ in leaves of different varieties of $C$. capsularis. Among the $C$. capsularis varieties CVL-1 showed the highest amount of $\beta$-carotene $22.28 \mathrm{mg} / 100 \mathrm{~g}$. Variety D-154 $(21.79 \mathrm{mg} / 100 \mathrm{~g}), \mathrm{BJC}-2197(21.21 \mathrm{mg} / 100 \mathrm{~g})$ and Deshi pat shak $-1(20.66 \mathrm{mg} / 100 \mathrm{~g})$ is comparable to variety CVL-1 having almost same level of $\beta$-carotene. Variety BJC-5003 and BJC-7370 contain $19.18 \mathrm{mg} / 100 \mathrm{~g}$ and $18.08 \mathrm{mg} / 100 \mathrm{~g} \beta$ carotene. BJC-83 and BJC-2142 have lowest $\beta$-carotene $11.34 \mathrm{mg} / 100 \mathrm{~g}$ and $12.32 \mathrm{mg} / 100 \mathrm{~g}$ respectively.

Table 1 Beta carotene content of leaves ofdifferent Corchorus olitorius and Corchorus capsularis varieties

\begin{tabular}{|c|c|c|}
\hline Species & Variety & Beta carotene conc. mg/100gm leaves \\
\hline \multirow{4}{*}{ Corchorus olitorius } & $0-3820$ & $28.93 \pm 0.54$ \\
\cline { 2 - 3 } & $0-795$ & $12.55 \pm 0.46$ \\
\cline { 2 - 3 } & $0-4$ & $29.05 \pm 0.42$ \\
\cline { 2 - 3 } & $0-72$ & $30.46 \pm 0.61$ \\
\cline { 2 - 3 } & $0-9897$ & $25.67 \pm 0.57$ \\
\cline { 2 - 3 } & OM-1 & $24.41 \pm 0.38$ \\
\cline { 2 - 3 } & MG-1 & $20.22 \pm 0.61$ \\
\hline
\end{tabular}


World Journal of Biology Pharmacy and Health Sciences, 2022, 09(02), 011-020

\begin{tabular}{|c|c|c|}
\hline \multirow{4}{*}{ Corchorus capsularis } & JRO-524 & $22.93 \pm 0.60$ \\
\cline { 2 - 3 } & Robi-1 & $39.93 \pm 0.49$ \\
\cline { 2 - 3 } & CVL-1 & $22.28 \pm 0.59$ \\
\cline { 2 - 3 } & CVE-3 & $15.87 \pm 0.42$ \\
\cline { 2 - 3 } & D-154 & $21.79 \pm 0.42$ \\
\cline { 2 - 3 } & CC-45 & $17.54 \pm 0.60$ \\
\cline { 2 - 3 } & BJC-2142 & $11.34 \pm 0.34$ \\
\cline { 2 - 3 } & BJC-7370 & $12.32 \pm 0.44$ \\
\cline { 2 - 3 } & BJC-5003 & $18.08 \pm 0.51$ \\
\cline { 2 - 3 } & BJC-2197 & $19.18 \pm 0.49$ \\
\cline { 2 - 3 } & Deshi pat shak -1 & $21.21 \pm 0.35$ \\
\hline
\end{tabular}

\subsection{Detection of $\beta$-carotene in jute leaves by TLC}

Figure 2 represents the thin layer chromatographic results of $\beta$-carotene in different varieties of $C$. olitorius leaves. Figure 3 represent the $\beta$-carotene in different varieties of $C$. capsularis leaves. It is observed in every TLC plate that $\beta$ carotene of the leaf sample reached to the similar position as the standard $\beta$-carotene did and orange colour of all the samples were distinct. Rf value of the jute leaves $\beta$-carotene is 0.82 in Table-2 (TLC plate-1) and 0.85 in Tbale-2 (TLC plate-2, 3and 4). Rx value of jute leaves $\beta$-carotene was 1.

Table $2 \mathrm{Rf}$ and Rx of Beta carotene of different varieties of jute leaves in TLC plate

\begin{tabular}{|c|c|c|c|c|}
\hline Jute species & TLC plate (Figure) & Sample designation & Rf & $\mathbf{R x}$ \\
\hline \multirow{11}{*}{ C. olitorius } & \multirow{6}{*}{$\begin{array}{c}\text { Plate } 1 \\
\text { (Fig. 2a) }\end{array}$} & Bc (standard $\beta$-carotene) & 0.82 & \\
\hline & & $\mathrm{O}_{1}(0-795)$ & 0.82 & 1 \\
\hline & & $\mathrm{O}_{2}(0-9897)$ & 0.82 & 1 \\
\hline & & $\mathrm{O}_{3}(0-72)$ & 0.82 & 1 \\
\hline & & $\mathrm{O}_{4}(\mathrm{O}-4)$ & 0.82 & 1 \\
\hline & & $\mathrm{O}_{5}(\mathrm{OM}-1)$ & 0.82 & 1 \\
\hline & \multirow{5}{*}{$\begin{array}{c}\text { Plate } 2 \\
\text { (Fig. 2b) }\end{array}$} & Bc (standard $\beta$-carotene) & 0.85 & \\
\hline & & $\mathrm{O}_{6}(0-3820)$ & 0.85 & 1 \\
\hline & & $\mathrm{O}_{7}(\mathrm{MG}-1)$ & 0.85 & 1 \\
\hline & & $\mathrm{O}_{8}($ Robi-1) & 0.85 & 1 \\
\hline & & $\mathrm{O}_{9}(\mathrm{JRO}-524)$ & 0.85 & 1 \\
\hline \multirow{6}{*}{ C. capsularis } & \multirow{6}{*}{$\begin{array}{l}\text { Plate } 3 \\
\text { (Fig. 3a) }\end{array}$} & Bc (standard $\beta$-carotene) & 0.85 & \\
\hline & & $\mathrm{C}_{1}(\mathrm{CVL}-1)$ & 0.85 & 1 \\
\hline & & $\mathrm{C}_{2}(\mathrm{D}-154)$ & 0.85 & 1 \\
\hline & & $\mathrm{C}_{3}(\mathrm{BJC}-7370)$ & 0.85 & 1 \\
\hline & & $\mathrm{C}_{4}(\mathrm{CC}-45)$ & 0.85 & 1 \\
\hline & & $\mathrm{C}_{5}(\mathrm{BJC}-2197)$ & 0.85 & 1 \\
\hline
\end{tabular}




\begin{tabular}{|l|l|c|c|c|}
\hline \multirow{4}{*}{$\begin{array}{l}\text { Plate -4 } \\
\text { (Fig. 3b) }\end{array}$} & Bc (standard $\beta$-carotene) & 0.85 & \\
\cline { 3 - 5 } & $\mathrm{C}_{6}$ (Deshi pat shak-1) & 0.85 & 1 \\
\cline { 3 - 5 } & $\mathrm{C}_{7}$ (BJC-83) & 0.85 & 1 \\
\cline { 3 - 5 } & $\mathrm{C}_{8}$ (BJC-2142) & 0.85 & 1 \\
\hline & $\mathrm{C}_{9}$ (BJC-5003) & 0.85 & 1 \\
\hline & $\mathrm{C}_{10}$ (CVE-3) & 0.85 & 1 \\
\hline
\end{tabular}

\section{Discussion}

B-carotene content shows variation in different varieties of jute leaves. Most of olitorius leaves contain higher $\beta$ carotene than the $\beta$-carotene content in leaves of $C$. capsularis. In some varieties of $C$. olitorius shows similarity with some $C$. capsularis varieties. MG-1 (20.22mg/100g) and JRO-524 (22.93) of $C$. olitorius varieties shows $\beta$-carotene content like varieties CVL-1(22.28mg/100g), D-154 (21.79mg/100g), BJC-2197 (21.2mg/100g) and deshi pat shak-1 $(20.66 \mathrm{mg} / 100 \mathrm{~g})$ of capsularis varieties. Olitorius variety $0-795$ shows $\beta$-carotene content $(12.55 \mathrm{mg} / 100 \mathrm{~g})$ like capsularis varieties BJC-2142 $(11.34 \mathrm{mg} / 100 \mathrm{~g})$ and BJC-83 $(12.32 \mathrm{mg} / 100 \mathrm{~g})$. Choudhary and his colleagues [29] mentioned that $C$. olitorius showed the highest amount of $\beta$-carotene among the 17 genotypes belonging to six jute species. They investigated $\beta$-carotene content in different Corchorus species including some varieties of $C$. olitorius. They observed most of the $C$. olitorius varieties have higher amount of $\beta$-carotene, some were similar, and some were lower than a capsularis variety (Table-3). In this study, jute leaves of different varieties showed higher amount of $\beta$ carotene (Table 1) than the previous report presented in Table-3 [29-31]. This may be occurred due to the geographical origin, genetic make-up, climate, soil condition and structure and fertilizers [32].

Table 3 Beta carotene content in jute leaves in previous report

\begin{tabular}{|c|c|c|c|}
\hline Species & Condition & $\beta$-carotene content & Reference \\
\hline \multirow[t]{4}{*}{ C. olitorius } & Fresh leaves & $9774.90 \mu \mathrm{g} / 100 \mathrm{~g}$ & \multirow{4}{*}{$\begin{array}{l}\text { Traoré et al., } \\
2019[30]\end{array}$} \\
\hline & $\begin{array}{l}\text { Cooked using ash leachet for } 15 \\
\text { and } 30 \mathrm{~min}\end{array}$ & $\begin{array}{c}3604.00 \mu \mathrm{g} / 100 \mathrm{~g} \text { and } \\
3768.80 \mu \mathrm{g} / 100 \mathrm{~g}\end{array}$ & \\
\hline & $\begin{array}{l}\text { Cooked in water for } 15 \text { and } \\
\text { 30min }\end{array}$ & $\begin{array}{l}2285.50 \mu \mathrm{g} / 100 \mathrm{~g} \text { and } \\
2365.00 \mu \mathrm{g} / 100 \mathrm{~g}\end{array}$ & \\
\hline & $\begin{array}{l}\text { Fried for } 5 \mathrm{~min} \text { following } 30 \mathrm{~min} \\
\text { cooking }\end{array}$ & $86.42 \%$ & \\
\hline C. fascicularis & \multirow{12}{*}{ Fresh leaves } & $62.67 \mathrm{mg} / \mathrm{kg}$ & \multirow{12}{*}{$\begin{array}{l}\text { Choudhary et } \\
\text { al., 2013 [29] }\end{array}$} \\
\hline C. triloculairs & & 36.00 & \\
\hline C. aestuans & & 76.33 & \\
\hline C. tridens & & 47.00 & \\
\hline C. capsularis (Maniksari) & & 61.33 & \\
\hline C. olitorius (Sudan Green) & & 81.33 & \\
\hline C. olitorius (Tanganyika) & & 79.70 & \\
\hline C. olitoruius (TJ-40) & & 64.00 & \\
\hline $\begin{array}{l}\text { C. olitorius (Bidhan } \\
\text { Rupali) }\end{array}$ & & 34.33 & \\
\hline C. olitorius (KOM -62) & & 63.67 & \\
\hline C. olitorius (JRO-66) & & 67.33 & \\
\hline C. olitorius (JRO-3690) & & 66.00 & \\
\hline
\end{tabular}




\begin{tabular}{|c|c|c|c|}
\hline C. olitorius (JRO-8432) & & 72.67 & \\
\hline C. olitorius (JRO-204) & & 51.00 & \\
\hline C. olitorius (JRO-524) & & 74.00 & \\
\hline C. olitorius (JRO-632) & & 53.33 & \\
\hline C. olitorius (S-19) & & 50.67 & \\
\hline \multirow{4}{*}{ C. capsularis (CVL-1) } & Fresh leaves & $7.82 \pm 0.16 \mathrm{mg} / 100 \mathrm{~g}$ & \multirow{4}{*}{$\begin{array}{l}\text { Ali et al., } 2020 \\
\text { [31] }\end{array}$} \\
\hline & Shade dried & $4.65 \pm 0.32$ & \\
\hline & Solar dried & $4.42 \pm 0.28$ & \\
\hline & Cooked & $3.81 \pm 0.42$ & \\
\hline
\end{tabular}

Thin layer chromatography results show the presence of $\beta$-carotene content in jute leaves. B-carotene from the leaf samples reached to the position which similar to the position of standard trans-beta carotene sample. Orange colour of the spot was visualized immediately in each variety of leaf samples in every TLC plate (Fig. 2 and 3). $\beta$-carotene is bright yellowish-orange due to a system of conjugated double bonds in its structure, it could be identified visually on the chromatogram without using any detecting reagents. The same occurrence observed during this experiment. The spots colours were visualized without any detecting reagent. Rf value of experimented samples were calculated high $(0.82 / 85)$. It was mentioned in previous report that non oxygenated carotenoids like $\beta$-carotene have higher $\mathrm{Rf}$ value $[33,34]$. Rx value is calculated 1.0 for all the $\beta$-carotene in leaves of different varieties of $C$. olitorius and $C$. capsularis (Table-2). Trans $\beta$-carotene was used as standard, so the Rx results show clear indication of presence of Trans $\beta$ carotene in fresh jute leaves.

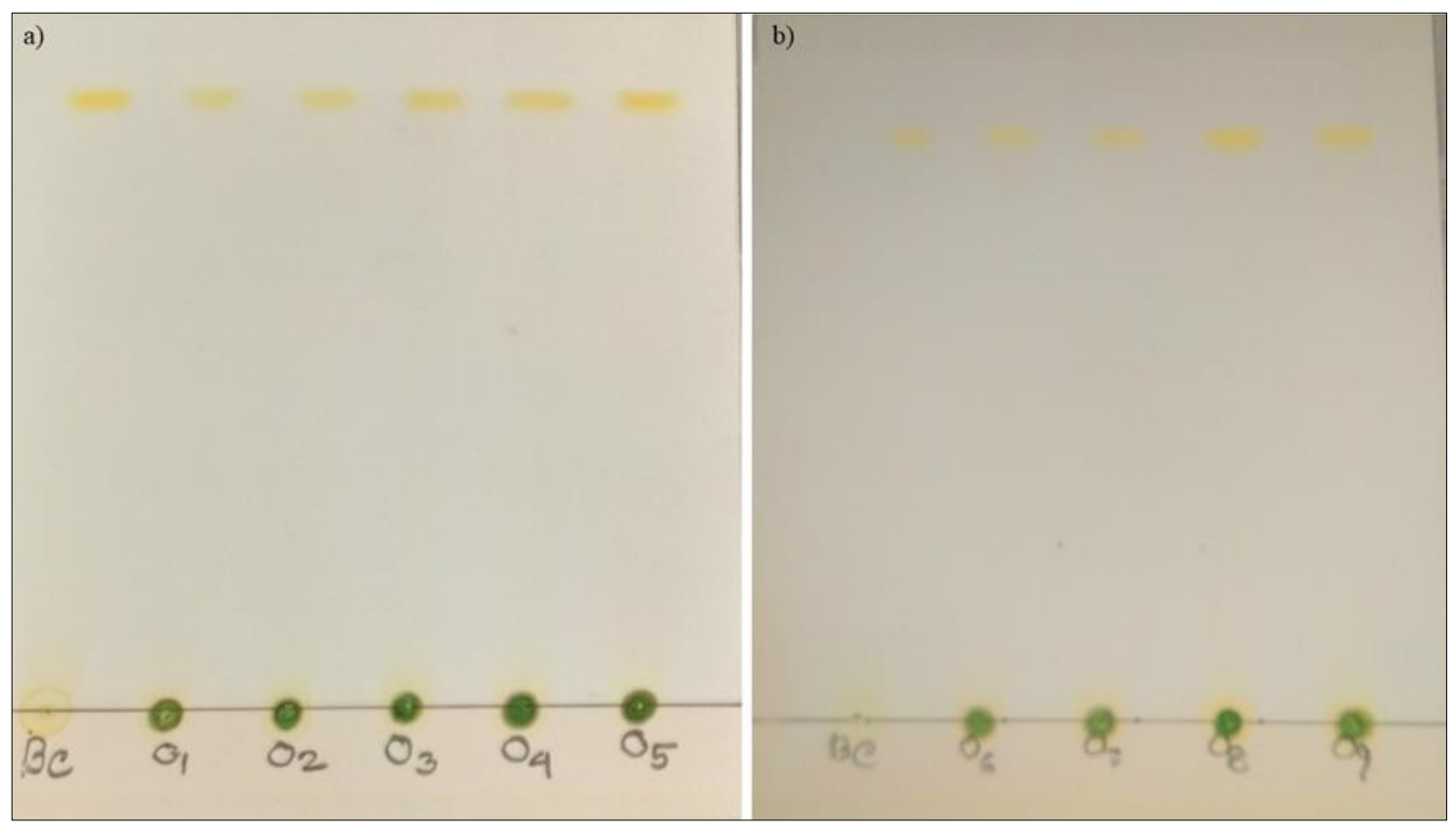

Figure $2 \beta$-carotene detection of nine varieties of $C$. olitorius leaves extract by TLC a) Bc, standard $\beta$-carotene; $\mathrm{O}_{1}, 0$ 795; $\mathrm{O}_{2}, \mathrm{O}-9897 ; \mathrm{O}_{3}, \mathrm{O}-72 ; \mathrm{O}_{4}, \mathrm{O}-4 ; \mathrm{O}_{5}, \mathrm{OM}-1$ b) Bc, standard $\beta$-carotene; $\mathrm{O}_{6}, \mathrm{O}-3820 ; \mathrm{O}_{7}, \mathrm{MG}-1 ; \mathrm{O}_{8}, \mathrm{Robi}-1 ; \mathrm{O}_{9}, \mathrm{JRO}-524$ 


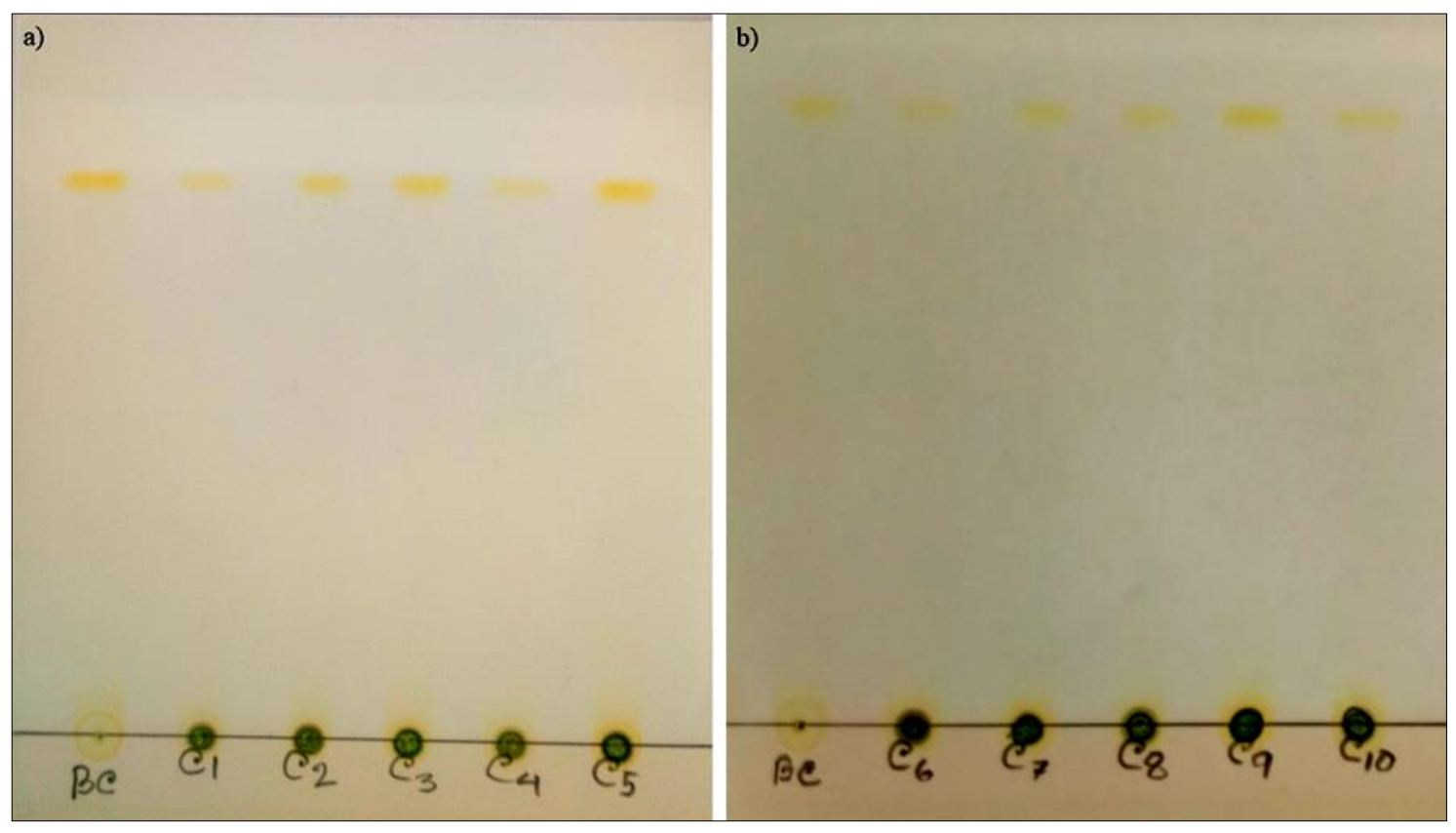

Figure $3 \beta$-carotene detection of ten varieties of $C$. capsularis leaves extract by TLC a) Bc, standard $\beta$-carotene; $\mathrm{C}_{1}, \mathrm{CVL}$ $1 ; \mathrm{C}_{2}, \mathrm{D}-154 ; \mathrm{C}_{3}, \mathrm{BJC}-7370 \mathrm{C}_{4}, \mathrm{CC}-45 ; \mathrm{C}_{5}, \mathrm{BJC}-2197$ b) Bc, standard $\beta$-carotene; $\mathrm{C}_{6}$, Deshi pat shak-1; $\mathrm{C}_{7}, \mathrm{BJC}-83$; $\mathrm{C}_{8}, \mathrm{BJC}-$ 2142; C9, BJC-5003; $\mathrm{C}_{10}, \mathrm{CVE}-3$

Carotenoids are insoluble in water but soluble in organic solvents. They present specific absorption spectra that help for their identification. In contact with air, they self-oxidate quickly and degrade [35]. Carotenoids require specific extraction and separation procedures due to its wide range of polarity. $\beta$-carotene is practically insoluble in water and hardly soluble even in methanol, acetonitrile or dimethyl sulfoxide [36-38]. Solubility is better in hexane, chloroform and dichloromethane (DCM), highest solubility was observed in Tetrahydrofuran (THF). In this experiment THF was used following DCM twice. So, the extraction process may be performed perfectly that may contribute for obtaining better results of $\beta$-carotene by spectrophotometer as well as by TLC. Extraction of carotenoids must be performed very quickly, avoiding exposure to light, oxygen and high temperature $[39,40]$. Nitrogen atmosphere is suggested for extraction of $\beta$-carotene to maintain cold environment. Here in this experiment cold environment was maintained in refrigerator. Extracted sample was dried at $4^{\circ} \mathrm{C}$ in refrigerator for $2 / 3$ days. The procedure followed neither nitrogen atmosphere nor quick procedure as mentioned in protocol, but it worked well. Thin layer chromatography results showed that good extraction was performed. TLC method is applied recently for separation and identification of complicated compounds such as carotenoids $[41,42]$. In Thin layer chromatography stationary phases are polar and mobile phases are nonpolar or low polarity. Early TLC methods used silica as stationary phase and a nonpolar mobile phase for separation of carotenoids [43-46]. It was also suggested that best separations could be achieved by use of adsorption TLC on alumina with hexane-chloroform mixtures as mobile phases [47]. In most cases petroleum ether with acetone was used major organic mobile phase [48-49]. Hexane was found to be the second major mobile phase used in TLC of carotenoids from plant sources $[50,51]$. In this TLC experiment silica gel on TLC Al foils were used as stationary phase and hexane was the non-polar mobile phase. B-carotene in jute leaves were detected well by this TLC system. Thin layer chromatography showed potentiality for separation and identification of carotenoids in vegetable and biological samples [52]. Our TLC reports for $\beta$-carotene detection of jute leaves are in agreement with this report.

\section{Conclusion}

Jute leaves are very rich in $\beta$-carotene content. Variation was found in $\beta$-carotene in jute leaves of different varieties. Most of the varieties in Corchorus olitorius species showed higher $\beta$-carotene than the varieties of Corchorus capsularis. In TLC system silica gel on TLC Al foils as stationary phase and hexane as mobile phase performed good separation and identification of $\beta$-carotene in jute leaves. 


\section{Compliance with ethical standards}

\section{Acknowledgments}

The authors thank Md. Shahidul Islam, Ph. D, former Principal Scientific Officer, Genetic Resources and Seed Division for critically reviewed the manuscript and also thank Dr. Nargis Akter, Chief Scientific Officer, Breeding Division, BJRI for kind cooperation of providing jute leaves from her experimental field.

\section{Disclosure of conflict of interest}

All authors declare that they have no conflict of interest.

\section{References}

[1] Westphal-Stevels J. Local vegetables in Cameroon: Corchorus species used as a vegetable. Acta Horticulturae. 1986; 182: 423-426.

[2] Kinabo J, Mnkeni AP, Nyaruhucha CNM, Msuya J, Haug A, Ishengoma J. Feeding frequency and nutrient content of foods commonly consumed in the Iringa and Morogoro regions in Tanzania. International Journal of Food Sciences and Nutrition. 2006; 57(1-2): 9-17.

[3] Nyadanu D, Lowor ST. Promoting competitiveness of neglected and underutilized crop species: comparative analysis of nutritional composition of indigenous and exotic leafy and fruit vegetables in Ghana. Genetic Resources and Crop Evolution. 2014; 62(1): 131-140.

[4] Steyn NP, Oliver J, Winter P, Burger S, Nesamvuni S. A survey of wild, green, leafy vegetables and their potential in combating micronutrient deficiencies in rural populations. South African Journal of Science. 2001; 97: 276279.

[5] Dansi A, Adajatin A, Adoukonou-Sagbadjia H, Faladé V, Yedomonhan H, Odou D, Dossou B. Traditional leafy vegetable and their use in the Benin Repubic. Genetic Resources and Crop Evolution. 2008; 55: 1239-1256.

[6] Nasreen A, Ahmed Z, Ali M, Shimu T. Jute leaves: A potential sources of lycopene. International Journal of Vegetable Sciences. 2022; 28(2): 180-188.

[7] Agbemafle R, Obodai EA, Adukpo GE, Amprako DN. Effects of boiling time on the concentrations of vitamin c and beta-carotene in five selected green vegetables consumed in Ghana. Advances in Applied Science Research. 2012; 3(5): 2815-2820.

[8] Traoré K, Parkouda C, Savadogo A, Hama F, Kamga R, Traoré Y. Effect of processing methods on the nutritional content of three traditional vegetables leaves: amaranth, black nightshade and jute mallow. Food Science and Nutrition. 2017; 5(6): 1139-1144.

[9] Miki W. Biological functions and activities of animal carotenoids. Pure and Applied Chemistry. 1991; 63(10):141146.

[10] Nishino H, Murakoshi M, Li T, Takemura M, Kuchide M, Knazawa M, Mou XY, Wada S, Masuda M, Ohsaka Y, Yogosawa S, Satomi Y, Jinno K. Carotenoids in cancer chemoprevention. Cancer Metastasis Reviews. 2002; 21: 257-264.

[11] Nishino H. Prevention of hepatocellular carcinoma in chronic viral hepatitis patients with cirrhosis by carotenoid mixture. Recent Results Cancer Research 2007; 174: 64-71.

[12] Lidebjer C, Leanderson P, Ernerudh J, Jonasson L. Low Plasma levels of oxygenated carotenoids in patients with coronary artery disease. Nutrition, metabolism, and cardiovascular diseases. 2007; 17: 448-456.

[13] Osganian SK, Stampfer MJ, Rimm E, Spiegelman D, Manson JE, Willett WC. Dietary carotenoids and risk of coronary artery disease in women. American Journal of Clinical Nutrition. 2003; 77: 1390-1399.

[14] Yamaguchi M, Uchiyama S. Effect of carotenoid on calcium content and alkaline phosphatase activity in rat femoral tissues in vitro: the unique anabolic effect of beta-cryptoxanthin. Biological and Pharmaceutical Bulletin. 2003; 26:1188-1191.

[15] Semba RD, Daganelie G. Are lutein and zeaxanthin conditionally essentials nutrients for eye health medical? Hypothesis. 2003; 61: 465-472. 
[16] Schalch W, Chon W, Barker FM. Köpcke W, Mellerio J, Bird AC, Robsn AG, Fitzke FF. van Kuijk FJGM. Xanthophyll accumulation in the human retina during supplementation with lutein or zeaxanthin-the LUXEA (Lutein xanthophylls Eye Accumulation) study. Archives of Biochemistry and Biophysics. 2007; 458:128-135.

[17] Sato Y, Akiyama H, Suganuma H, Watanabe T., Nagaoka MH, Inakuma T, Goda Y, Maitani T. The Feeding of betacarotene down-regulates serum IgE levels and inhibits the type I allergic response in mice. Biological and Pharmaceutical Bulletin. 2004; 27: 978-984.

[18] Hughes DA. Dietary carotenoids and human Immune function. Nutrition. 2001; 17: 978-984.

[19] Okai Y, Higashi-Okai K. Possible immune modulating activities of carotenoids in in vitro cell culture experiments. International Journal of Immunopharmacology. 1996; 18: 753-758.

[20] Stuerenburg HJ, Ganzer S, Muller-Thomsen T. Plasma beta carotene in Alzheimer's disease. Association with cerebrospinal fluid beta-amyloid 1-40 (Abeta40), beta-amyloid 1-42(Abta42) and total Tau. Neuroendocrinology Letters. 2005; 26: 696-698.

[21] Johnson EJ. The role of carotenoids in human health. Nutrition in Clinical Care. 2002; 5:56-65.

[22] Agarwal S, Rao AV. Carotenoids and chronic diseases. Drug Metabolism and Drug Interactions. 2000; 17:189-210.

[23] Elliott R. Mechanisms of genomic and nongenomic actions of carotenoids. Biochimica et Biophysica Acta. 2005; 1740(2): 147-154.

[24] Bendich A, Olson JA. Biological actions of carotenoids. FASEB Journal. 1989; 3:1927-1932.

[25] Muthoni J, Nyamongo DO, Silingi M. Participatory characterization and evaluation of some African leafy vegetables in Lari, Kiambu West District, Central Kenya. Journal of Horticulture and Forestry. 2010; 2(2): 12-16.

[26] Chowdhury MAH, Hassan MS. Handbook of agricultural technology. Bangladesh Agricultural Research Council, Dhaka, Bangladesh. 2013.

[27] Karnjanawipagul P, Nittayanuntawech W, Rojsanga P, Suntornsuk L. Analysis of $\beta$-Carotene in Carrot by Spectrophotometry. Mahidol university Journal of Pharmaceutical Science. 2010; 37(1-2): 8-16.

[28] Herrero-Martinez JM, Eeltink, Schoenmakers PJ, Kok WT, Ramis-Ramos G. Determination of major carotenoids in vegetables by capillary electrochromatography. Journal of Separation Science. 2006; 29: 660-665.

[29] Choudhary SB, Sharma HK, Karmakar PG, Kumar A, Saha AR, Mahapatra BS. Nutritional profile of cultivated and wild jute (Corchorus) species. Australian Journal of Crop Science. 2013; 7(13): 1973-1982.

[30] Traoré K, Parkouda C, Savadogo A, Ba/Hama F, Kamga R, Traoré Y. Effect of processing methods on the nutritional content of three traditional vegetables leaves: Amaranth, black nightshade and jute mallow. Food Science and Nutrition. 2017; 5(6): 1139-1144.

[31] Ali MM, Rahman MT, Ahmed T, Rokeya B, Roy B. Advance Research on Nutraceutical Composition of Mature Jute Leaves. International Journal of Recent Innovations in Medicine and Clinical Research. 2020; 2(4): $124-137$.

[32] Rodriguez-Amaya DB. Carotenoids and food preparation: The retention of provitamin A carotenoids in prepared, processed, and stored foods, Department of Food Science, University of Campinas, C.P. 6121, 13083-970 Campinas, SP., Brazil. 1997.

[33] Mariana G, Corina M, Alina C, Sanda B. Determination of carotenoids by thin layer chromatography. Annals of the University of Oradea, Environmental Protection Issue. 2016; XXVI.

[34] Perucka I, Oleszek W. Extraction and determination of capsaicinoids in fruit of hot pepper Capsicum annuum L. by spectrophotometry and high-performance liquid chromatography. Food Chemistry. 2000; 71(2): $287-291$.

[35] Britton G, Liaaen-Jensen S, Pfander H. Carotenoids. vol 4, Natural functions. Birkhäuser Verlag, Basel. $2008 ; 431$.

[36] Feltl L, Pacakova V, Stulik K, Volka K. Reliability of carotenoid analyses: A review. Current Analytical Chemistry. 2005; 1: 93-100.

[37] Aust O, Sies H, Stahl W, Polidori MC. Analysis of lipophilic antioxidants in human serum and tissues: tocopherols and carotenoids. Journal of Chromatography. 2001; 936: 83-93.

[38] Craft NE, Soares JH. Relative solubility, stability, and absorptivity of lutein and $\beta$-carotene in organic solvents. Journal of Agricultural Food Chemistry. 1992; 40: 431-434. 
[39] Van den Berg H, Faulks R, Granado HF, Hirschberg J, Olmedilla B, Sandmann G, Southon S, Stahl W. The potential for the improvement of carotenoid levels in foods and the likely systemic effects. Journal of the Science of Food and Agriculture. 2000; 80: 880-912.

[40] Marsili R, Callahan D. Comparison of a liquid solvent extraction technique and supercritical fluid extraction for the determination of alpha- and beta-carotene in vegetables. Journal of Chromatography Science. 1993; 31(10): 422-428.

[41] Checheta OV, Safonova EF, Slivkin AI. Thin-layer chromatography characteristics of [beta]-carotene. Pharmaceutical Chemistry Journal. 2012; 46(5): 321.

[42] Kirchner JG, Thin Layer Chromatography, 2nd Ed., Techniques of Chemistry, Vol.14 Somerset, New Jersey, U.S.A. 1978.

[43] Cserhati T, Forgacs E. Liquid chromatographic separation of terpenoid pigments in foods and food products. Journal of Chromatography A. 2001; 936(1-2): 119-137.

[44] Vinkler M, Kiszel-Richter M. A thin layer chromatographic method to determine the pigment content (components) in the pericarb of paprika. Acta Aliment. 1972; 1: 41-58.

[45] Buckle KA, Rahman FMM. Separation of chlorophyll and carotenoid pigments of capsicum cultivars. Journal of Chromatography A. 1979; 171: 385-391.

[46] Cserhati T, Forgacs E, Hollo J. Separation of color pigments of capsicum-annuum by adsorption and reversedphase thin-layer chromatography. Journal of Planar Chromatography. 1993; 6(6): 472-475.

[47] Forgacs E, Cserhati T. Thin-layer chromatography of natural pigments: new advances. Journal of Liquid Chromatography \& Related Technologies. 2002; 25(10-11): 1521-1541.

[48] Ren D, Zhang S. Separation and Identification of the Yellow Carotenoids in Potamogeton crispus L. Food Chemistry. 2008; 106(1): 410-414.

[49] Melendez-Martinez AJ, Britton G, Vicario IM, Heredia FJ. HPLC analysis of geometrical isomers of lutein epoxide isolated from dandelion (Taraxacum officinale F. Weber ex Wiggers). Phytochemistry. 2006; 67(8): 771-777.

[50] Liu H, Kao T, Chen B. Determination of Carotenoids in the Chinese Medical Herb Jiao-Gu-Lan (Gynostemma Pentaphyllum MAKINO) by Liquid Chromatography. Chromatographia. 2004; 60: 411-417.

[51] Rao AR, Sarada R, Ravishankar GA. Stabilization of astaxanthin in edible oils and its use as an antioxidant. Journal of the Science of Food and Agriculture. 2007; 87(6): 957-965.

[52] Zeb A, Murkovic M. Thin-Layer Chromatographic Analysis of Carotenoids in Plant and Animal Samples. Journal of Planar Chromatography. 2010; 23: 94-103. 